Michael, Yugih Setyanto: Strategi Public Relations dalam Membangun Solidaritas (Studi Pada Komunitas Motor Icon)

\title{
Strategi Public Relations dalam Membangun Solidaritas (Studi Pada Komunitas Motor Icon)
}

\author{
Michael, Yugih Setyanto \\ michael.ik@stu.untar.ac.id,yugihs@fikom.untar.ac.id \\ Fakultas Ilmu Komunikasi Universitas Tarumanagara
}

\begin{abstract}
Communication has an important role in a community to support high solidarity between members. But not all communities know what things can build solidarity between members. Therefore, administrators in the community think about how to build solidarity within the group, how to keep the group members afloat, and also how to maintain group members so that they still have a family attitude and also care for one another. Of course in this community, some members are chosen to be community administrators, and changed every year. Some of these members have roles as chairperson, public relations officer, and treasurer. The role of a chairperson includes many things, managing members, organizing events, looking for useful information for the community and also building cohesiveness within the community. The communication process that takes place in ICON uses the Laswell communication model which is one-way, i.e. the community leader gives direction to community members directly or through WhatsApp group media. The approach used in this research is descriptive-qualitative and with the case study method. The research subject in this study was ICON. While the object of research in this study is the communication process in forming solidarity that is used by ICON in increasing solidarity within groups and also building a good image in the eyes of the community. Data collected by interview, documentation, and literature study. The conclusion of this study is that ICON uses communication strategies in the form of publications, events, community participation, CSR. In addition, to build the solidarity of its members, ICON often holds touring, Sunday morning rides, and kopdar.
\end{abstract}

Keywords: communication, image, motorcycle community, solidarity.

\begin{abstract}
Abstrak
Komunikasi mempunyai peran penting dalam sebuah komunitas untuk menunjang solidaritas yang tinggi antar anggota. Namun tidak semua komunitas mengetahui hal-hal apa saja yang dapat membangun solidaritas antar anggota. Oleh karena itu, pengurus di dalam komunitas tersebut memikirkan bagaimana cara membangun solidaritas dalam kelompok, bagaimana cara menjaga anggota kelompok tetap bertahan, dan juga bagaimana memelihara anggota kelompok agar tetap memiliki sikap kekeluargaan dan juga saling peduli satu sama lain. Dalam komunitas ini, beberapa anggota dipilih untuk menjadi pengurus komunitas, dan berganti setiap tahunnya. Beberapa anggota tersebut memiliki peran sebagai ketua, humas, dan bendahara. Peran seorang ketua mencakup banyak hal diantaranya mengurus anggota, mengadakan acara, mencari info-info yang bermanfaat untuk komunitas dan juga membangun kekompakan. Pendekatan yang digunakan dalam penelitian ini adalah kualitatif deskriptif dan dengan metode studi kasus. Subjek penelitian pada penelitian ini adalah komunitas motor ICON. Sedangkan objek penelitian pada penelitian ini adalah proses komunikasi dalam membentuk solidaritas yang digunakan oleh komunitas motor ICON dalam meningkatkan solidaritas dan membangun citra yang baik di pandangan masyarakat. Data dikumpulkan dengan wawancara, dokumentasi, dan studi pustaka. Kesimpulan dari penelitian ini adalah komunitas motor menggunakan strategi komunikasi berupa publications, event, community
\end{abstract}


involvement, CSR. Selain itu, untuk membangun solidaritas anggotanya, komunitas motor mengadakan touring, sunday morning ride, dan kopi darat.

Kata Kunci: citra, komunikasi, komunitas motor, solidaritas

\section{Pendahuluan}

Sebagai makhluk sosial, manusia akan selalu membutuhkan orang lain untuk berinteraksi baik dalam hubungan antara dua orang atau kelompok. Dapat dikatakan bahwa komunikasi dan interaksi adalah hal utama yang dibutuhkan manusia. Interaksi antara sesama manusia menunjukkan bahwa setiap orang membutuhkan bantuan dari orang lain. Pada umumnya setiap manusia memiliki gaya hidup tersendiri, dan biasanya manusia akan mencari orang lain yang memiliki kesamaan dalam hal yang disukai dan membentuk sebuah komunitas.

Komunitas adalah suatu kelompok sosial, dan yang dimaksud kelompok sosial adalah suatu kumpulan orang yang saling bekerja sama, saling berinteraksi dan saling menyadari kepentingan antara sesama anggotanya. Menurut George Homans, kelompok sosial yaitu kumpulan individu yang melakukan kegiatan, interaksi dan perasaan untuk membentuk suatu keseluruhan yang terorganisasi dan berhubungan timbal balik. Dalam sebuah kelompok biasanya memiliki satu hal yang ingin dicapainya, dan memberikan dampak kepada para anggota kelompok.

Setiap komunitas mempunyai suatu hal yang unik yang membuat mereka berbeda dari komunitas lain, salah satu komunitas yang akan menjadi sumber penulis adalah komunitas motor Indonesia CBR250RR Owners (ICON). Salah satu keunikan yang membuat komunitas ini berbeda dari komunitas lain adalah anggotanya yang menggunakan motor yang sama. Komunitas ini bersifat bebas karena tidak memiliki peraturan yang diwajibkan, beberapa aturan yang ada di komunitas ini adalah wajib menggunakan perlengkapan berkendara yang dianjurkan dan memiliki surat-surat berkendara yang lengkap. Salah satu alasan mengapa penulis memilih untuk melakukan penelitian adalah, di dalam komunitas ini tidak memandang usia dan juga perbedaan. Setiap individu memiliki kebebasan untuk bergabung ke dalam komunitas ini, baik itu anak muda yang berumur 18 tahun keatas, maupun wanita. Komunitas ini menghargai perbedaan yang ada.

Komunitas adalah suatu kelompok sosial, dan yang dimaksud kelompok sosial adalah suatu kumpulan orang yang saling bekerja sama, saling berinteraksi dan saling menyadari kepentingan antara sesama anggotanya. Menurut salah satu ahli yang bernama George Homans, kelompok sosial yaitu kumpulan individu yang melakukan kegiatan, interaksi dan perasaan untuk membentuk suatu keseluruhan yang terorganisasi dan berhubungan timbal balik. Dalam sebuah kelompok biasanya memiliki satu hal yang ingin dicapainya, dan memberikan dampak kepada para anggota kelompok.

\section{Metode Penelitian}

Dalam penelitian ini, penulis memilih menggunakan metode penelitian kualitatif dengan pendekatan studi kasus. Menurut Creswell, studi kasus merupakan strategi penelitian dimana di dalamnya peneliti menyelidiki secara cermat suatu program, peristiwa, aktivitas, proses, atau sekelompok individu (Creswell, 2010) Praktek studi kasus adalah suatu penelitian yang dilakukan secara intensif, terperinci, dan mendalam terhadap suatu organisasi, lembaga atau gejala tertentu (Arikunto,2002) 
Michael, Yugih Setyanto: Strategi Public Relations dalam Membangun Solidaritas (Studi Pada Komunitas Motor Icon)

Menurut Bajari (2015), penelitian kualitatif merupakan sebuah upaya menggali data secara sistematis dimana peneliti berperan sebagai instrumen yang harus menangkap semua teks verbal dan nonverbal serta situasi menjadi data penelitian. Semua dilakukan dalam suasana sewajarnya, normal, alamiah, dan sukarela. Bahkan informan hampir tidak merasakan diobservasi atau diteliti. Sementara menurut Moleong (2010), penelitian kualitatif adalah penelitian yang bermaksud untuk memahami fenomena tentang apa yang dialami oleh subjek penelitian. Penulis menggunakan metode tersebut karena sejalan dengan rumusan masalah penulis yaitu untuk mengetahui bagaimana komunikasi membentuk solidaritas di dalam komunitas motor ICON.

\section{Hasil Penemuan dan Diskusi}

Komunitas motor merupakan sekumpulan pengendara sepeda motor atau bikers yang tergabung dalam suatu perkumpulan. Pada umumnya, setiap komunitas memiliki sebuah tempat berkumpul bersama. Komunitas motor pada jaman sekarang semakin berkembang karena di dalam sebuah komunitas, orang-orang yang memiliki ketertarikan yang sama di dalam dunia otomotif berkumpul, dan saling berbagi informasi.

Hingga tahun ini, sudah sangat banyak komunitas motor yang berkembang di seluruh dunia, dan semua komunitas motor memiliki perbedaan. Hal tersebut yang membuat orang-orang yang memiliki ketertarikan yang sama mewajibkan dirinya untuk bergabung dengan komunitas yang sesuai dengan apa yang dia sukai.

Banyak masyarakat menyamakan komunitas motor dengan geng motor ugalugalan dan anarkis. Pada umumnya para bikers memakai perlengkapan yang sesuai sedangkan anggota geng motor memakai perlengkapan seadanya. Hal ini membuat semua komunitas motor khususnya ICON berusaha membangun citra yang baik di hadapan masyarakat dan tentunya berusaha untuk tidak meresahkan masyarakat.

Fungsi PR di dalam komunitas motor ICON menjadi penting. Menurut Firsan Nova (2011), fungsi utama PR adalah menumbuhkan dan mengembangkan hubungan baik antar lembaga (organisasi) dengan publiknya, internal maupun eksternal dalam rangka menanamkan pengertian, menumbuhkan motivasi dan partisipasi publik dalam upaya menciptakan iklim pendapat (opini publik) yang menguntungkan lembaga organisasi.

Bertrand R. Canfield menjelaskan tiga fungsi public relations yaitu: a) mengabdi kepada kepentingan umum (it should serve the public interest); b) memelihara komunikasi yang baik (maintain good communication); c) menitikberatkan moral dan tingkah laku yang baik (stress good moral and manners). (Effendy, 2009).

\section{Strategi PR Dalam Komunitas ICON}

Publications merupakan kegiatan menyebarluaskan informasi melalui berbagai media mengenai aktivitas atau kegiatan organisasi kepada publik. Tujuan dari publikasi adalah untuk melihat minat publik terhadap kegiatan yang dibagikan di media sosial. Hal ini menjadi kelancaran penyampaian penyebarluasan informasi. Lesly (1992) menjelaskan definisi publikasi adalah penyebaran pesan yang direncanakan dan dilakukan untuk kepentingan tertentu dari organisasi dan perorangan tanpa pembayaran kepada media. Dalam hal ini, komunitas motor ICON menyebarluaskan kegiatannya melalui media sosial Instagram. Hal ini bertujuan agar 
publik dapat mengetahui informasi mengenai kegiatan yang dilakukan oleh komunitas motor ICON.

Event merupakan kegiatan yang diadakan untuk memperkenalkan komunitas dan untuk mendekatkan diri ke publik dan memperat hubungan antar anggota. Komunitas motor ICON mempunyai agenda rutin seperti touring yang diadakan setahun sekali hingga dua kali, dan Sunday Morning Ride yang diadakan setiap Minggu pagi. Kegiatan ini diadakan untuk memperat solidaritas dalam komunitas dan mengajak para anggotanya untuk mendekatkan diri dengan alam.

Community involvement merupakan kegiatan untuk mengadakan kontak sosial dengan kelompok masyarakat tertentu untuk menjaga hubungan baik dengan pihak organisasi atau lembaga yang diwakilinya. Manfaat dari community involvement adalah membangun reputasi dan citra komunitas yang lebih baik serta peluang menciptakan kerja sama dan pengalaman baru. Dalam hal ini, komunitas motor IKON seringkali menghadiri acara atau kegiatan komunitas motor lainnya seperti acara ulang tahun. Hal ini dilakukan untuk membangun hubungan yang baik antar komunitas.

Secara tradisional, PR mengelola hubungan dengan media melalui berbagai cara seperti mengirim press release, mengatur wawancara, menyiapkan press conference, dan merespon permintaan media terhadap perusahaan. Namun seiring kemajuan teknologi, hubungan media mengalami perubahan dengan adanya media sosial (Setyanto, 2016)

Social responbility merupakan tanggung jawab sosial untuk menunjukkan bahwa komunitas tersebut memiliki kepedulian terhadap masyarakat. Dalam hal ini, komunitas motor ICON melakukan kegiatan bakti sosial seperti mengumpulkan dana dan pakaian bekas ke korban bencana Palu.

Penulis menyimpulkan bahwa strategi PR yang dilakukan oleh ICON melalui publications, event, community involvement, dan social responsibility berhasil membangun dan mengelola citra untuk mencapai tujuan komunitas tersebut.

\section{Simpulan}

Munculnya komunitas motor ICON didasari keinginan para pemilik motor Honda CBR250RR yang ada di Jakarta untuk mempersatukan pemilik motor sama di seluruh Jakarta. Anggotanya menunjukan eksistensi terhadap hobi mereka sebagai pecinta motor Honda CBR250RR yang kemudian membentuk sebuah komunitas sebagai wadah untuk menyalurkan hobi mereka.

Kemunculan komunitas motor ICON juga memiliki tujuan untuk membedakan komunitas ini dengan komunitas lain. Dengan adanya komunitas motor ICON, membuat komunitas ini berbeda dengan komunitas lain yang kebanyakan memiliki anggota dengan motor yang berbeda-beda. Komunitas motor ICON hanya memiliki anggota yang memiliki motor yang sama.

Komunitas motor ICON mempunyai ikatan yang solidaritas internal yang kuat dan ditujukan kepada sesama anggota ICON. Ikatan tersebut meliputi pertemanan, kekeluargaan, dan tolong menolong. Solidaritas juga tumbuh karena adanya ikatan yang terjalin sesama anggota, selain itu juga tumbuh melalui kegiatan-kegiatan dan aktivitas yang telah dilakukan bersama oleh setiap anggota. Misalnya kegiatan touring, Sunday morning ride, dan Acara amal. 
Michael, Yugih Setyanto: Strategi Public Relations dalam Membangun Solidaritas (Studi Pada Komunitas Motor Icon)

Solidaritas eksternal komunitas ICON dengan komunitas motor lainnya merupakan kerjasama di antara mereka. Kerjasama yang biasanya dilakukan antar komunitas seperti touring, maupun mengundang komunitas lain ke acara ulang tahun komunitas mereka.

\section{Ucapan terima kasih}

Penulis mengucapkan rasa syukur dan terima kasih atas penyelesaian penelitian ini kepada Fakultas Ilmu Komunikasi Universitas Tarumanagara dan para narasumber yang sudah meluangkan waktu untuk penulis dalam menyelesaikan penelitian ini dengan singkat, jelas, dan padat tanpa kekurangan kata-kata apapun.

\section{Daftar Pustaka}

Arikunto, S. (2002). Prosedur Penelitian Suatu Pendekatan Praktek. Jakarta: Asdi Mahasatya.

Baljari, Atwar. (2015) Metode Penelitian Komunikasi. Bandung: PT. Remaja Rosdakarya

Creswell, John W. (2010) Penelitian Kualitatif Dan Desain Riset. Pustaka Pelajar

Effendy, Onong Uchjana. 2009. Komunikasi teori dan praktek. Bandung: PT Remaja Rosdakarya.

Hennink, M., Hutter, I., dan Bailey, A., (2011), Qualitative Research Methods, London: Sage Publications.

Moleong, Lexy J. (2010) Metodologi Penelitian Kualitatif Edisi Revisi. Bandung: PT.Remaja Rosdakarya

Nova, Firsan. (2011). Crisis Public Relation. Jakarta: Raja Grafindo Persada

Sandjaja, B. Albertus heriyanto. (2006). Panduan Penelitian. Jakarta: Prestasi Pustaka.

Sujarweni, V. Wiratna. (2014). Metode Penelitian: Lengkap, Praktis, dan Mudah Dipahami. Yogyakarta: Pustaka Baru Press.

Yugih Setyanto, Paula T. Anggarina. (2016). Media Sosial sebagai Sarana Komunikasi Perusahaan dengan Media. 